MASTERS OF THE MIDDLE WATERS 



\title{
MASTERS of the MIDDLE WATERS
}

\author{
Indian Nations and Colonial Ambitions \\ along the Mississippi
}

JACOB F. LEE

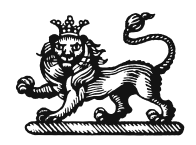

THE BELKNAP PRESS OF

HARVARD UNIVERSITY PRESS

Cambridge, Massachusetts

London, England

2019 
Copyright (C) 2019 by the President and Fellows of Harvard College All rights reserved

Printed in the United States of America

First printing

Cover Art: Henry Lewis, Falls of Saint Anthony, Upper Mississippi, 1847. (C) Museo Thyssen-Bornemisza, Madrid, SpainTarker/Bridgeman Images

Cover design: Annamarie McMahon Why

$$
\begin{aligned}
& 9780674239784 \text { (EPUB) } \\
& 9780674239791 \text { (MOBI) }
\end{aligned}
$$$$
9780674239777 \text { (PDF) }
$$

The Library of Congress has cataloged the printed edition as follows:

Names: Lee, Jacob F., author.

Title: Masters of the middle waters : Indian nations and colonial ambitions along the Mississippi / Jacob F. Lee.

Description: Cambridge, Massachusetts : The Belknap Press of Harvard University Press, 2019. | Includes bibliographical references and index. Identifiers: LCCN 2018039441 | ISBN 9780674987678 (cloth)

Subjects: LCSH: Indians of North America-Mississippi River Valley-Politics and government. | Indians of North America-Mississippi River Valley-History. | Indians of North America-Kinship-Mississippi River Valley. | Illinois Indians-History. | Illinois Indians-Politics and government. | Indians, Treatment of-Mississippi River Valley. | Mississippi River Valley-History. | Europe-Colonies-America-History. Classification: LCC E78.M75 L44 2019 | DDC 977 / .01—dc23

LC record available at https://lccn.loc.gov/2018039441 
To my family 
